\title{
Anti-NMDAR encephalitis
}

\section{A single-center, longitudinal study in China}

Xiaolu Xu, MD,* Qiang Lu, MD, * Yan Huang, MD, Siyuan Fan, MD, Lixin Zhou, MD, Jing Yuan, MD, Xunzhe Yang, MD, Haitao Ren, BS, Dawei Sun, MD, Yi Dai, MD, Huadong Zhu, MD, Yinan Jiang, MD, Yicheng Zhu, MD, Bin Peng, MD, Liying Cui, MD, and Hongzhi Guan, MD

Correspondence

Dr. Guan

guanhz@263.net

Neurol Neuroimmunol Neuroinflamm 2020;7:e633. doi:10.1212/NXI.0000000000000633

\section{Abstract}

\section{Objective}

To describe the detailed clinical characteristics, immunotherapy, and long-term outcomes of patients with anti-NMDA receptor (NMDAR) encephalitis in China.

\section{Methods}

A single-center, prospective study. Patients who met the diagnostic criteria were enrolled from 2011 to 2017 and followed up. The clinical features, treatment, and long-term outcomes were collected prospectively. Factors affecting the long-term prognosis were analyzed.

\section{Results}

The study included 220 patients. The most common clinical presentations were psychosis $(82.7 \%)$ and seizures $(80.9 \%)$. Of the patients, $19.5 \%$ had an underlying neoplasm; of which ovarian teratoma was $100 \%$ of tumors in females and only one male had lung cancer. Most patients (99.5\%) received first-line therapy (glucocorticoids, IV immunoglobulin, or plasmapheresis alone or combined), and only 7.3\% received second-line immunotherapy (rituximab, cyclophosphamide alone, or combined). Long-term immunotherapy (mycophenolate mofetil or azathioprine $>1$ year) was administered to $53.2 \%$ of patients. During the first 12 months, 207 (94.1\%) patients experienced improvement, and 5 (2.3\%) died, whereas 38 (17.3\%) experienced relapses. At 12-month follow-up, $92.7 \%$ had favorable clinical outcomes (modified Rankin Scale score $\leq 2$ ).

\section{Conclusions}

Patients in China present with psychosis and seizure frequently but have a low percentage of underlying neoplasms. Re-enforced first-line immunotherapy is effective in managing antiNMDAR encephalitis in the acute phase. Although relapse is relatively common, with combined first-line and long-term immunotherapy, most patients reached favorable outcomes.

\footnotetext{
*These authors contributed equally to the manuscript.

From the Department of Neurology (X.X., Q.L., Y.H., S.F., L.Z., J.Y., X.Y., H.R., Y.Z., B.P., L.C., H.G.), Department of Gynecology and Obstetrics (D.S., Y.D.), Department of Emergency (H.Z.), and Department of Psychology (Y.J.), Peking Union Medical College Hospital, Chinese Academy of Medical Sciences and Peking Union Medical College, Beijing, China; and Center of Neuroscience (L.C.), Chinese Academy of Medical Sciences.

Go to Neurology.org/NN for full disclosures. Funding information is provided at the end of the article.

The Article Processing Charge was funded by National Key Research and Development Program of China (Grant no. 2016YFC0901500); Center for Rare Diseases Research, Chinese Academy of Medical Sciences, Beijing, China (Grant no. 2016ZX310174-4); and Beijing Municipal Science and Technology Foundation (Grant no. Z161100000516094). 


\section{Glossary}

AE = autoimmune encephalitis; AQP4 = aquaporin-4; AZA = azathioprine; CTX = cyclophosphamide; HSV = herpes simplex virus; ICU = intensive care unit; IQR = interquartile range; IVIG = IV immunoglobulin; $M M F=$ mycophenolate mofetil; MOG = myelin oligodendrocyte glycoprotein; $\mathbf{m R S}=$ modified Rankin Scale; $\mathbf{M T X}=$ methotrexate; NMDAR = NMDA receptor; PE = plasmapheresis; PUMCH = Peking Union Medical College Hospital; RTX = rituximab.

Anti-NMDA receptor (NMDAR) encephalitis is the most common type of autoimmune encephalitis (AE), which is associated with autoantibodies against neurosurface or synaptic antigens. ${ }^{1-3}$ Since its first report in $2007,{ }^{1}$ with the proposed clinical approach, ${ }^{3}$ increasing numbers of antiNMDAR encephalitis cases were identified.

Differences in clinical characteristics and treatment strategies of anti-NMDAR encephalitis were reported among races and countries. $^{4-10}$ Main barriers to $\mathrm{AE}$ management in China consist of the availability of referral centers, the timeliness of correct diagnosis, and financial concerns. ${ }^{11}$ In 2017, China proposed a domestic consensus on the management of $\mathrm{AE}$, aiming to increase awareness of the disease and determine the optimal treatment for Chinese patients. ${ }^{12}$ However, limited data of clinical characteristics and long-term prognosis of Chinese anti-NMDAR patients are available owing to few reports with small sample size., ${ }^{9,11,13,14}$

Taking the advantage of Peking Union Medical College Hospital (PUMCH) as the national referral center for complicated disease, a prospective anti-NMDAR encephalitis disease cohort was established to describe the clinical characteristics, treatment regimen, and long-term outcomes of patients with anti-NMDAR encephalitis in China.

\section{Methods}

\section{Study design and population}

In this study, patients with anti-NMDAR encephalitis were enrolled consecutively at PUMCH between May 2011 and December 2017. The inclusion criteria were as follows: (1) acute onset of 1 or more of the 8 major groups of manifestations: psychosis, memory deficit, speech disturbance, seizures, movement disorder, loss of consciousness, autonomic dysfunction, and central hypoventilation; (2) CSF tested positive for NMDAR antibodies (cell-based assay [EUROIMMUN, Lübeck, Germany]); and (3) reasonable exclusion of other disorders.

To better understand the clinical characteristics, we also recorded the co-occurrence of fever, headache, arrhythmia, intensive care unit (ICU) admission, and other atypical symptoms. Because of limited resources of the hospital and financial concerns the patients, the absolute indications for ICU admission included severe anti-NMDAR encephalitis with ovarian teratoma requiring surgical operation, status epilepticus, mechanical ventilation requirement, and hemodynamic instability.
Demographic data and ancillary tests results were recorded, including age at onset, sex, disease course, CSF tests results, MRI, and EEG results. All patients were screened at least once for systemic tumors at onset. Patients with tumors underwent tumor removal. Immunotherapy included first-line (corticosteroids, IV immunoglobulin [IVIG], or plasmapheresis $[\mathrm{PE}]$ alone or combined) and second-line (rituximab [RTX] and cyclophosphamide [CTX] alone or combined) immunotherapies. ${ }^{6,7}$ Long-term immunotherapy (mycophenolate mofetil $[\mathrm{MMF}]$ or azathioprine $[\mathrm{AZA}]>1$ year) and other immunotherapy (intrathecal methotrexate $[\mathrm{MTX}]$ ) were also administered. ${ }^{15,16}$

Patients were followed regularly in local hospitals or PUMCH neurology clinics. Treatment effects and long-term outcomes were assessed using the modified Rankin Scale (mRS). A poor response was defined as no improvement in the $\mathrm{mRS}$ score or as an $\mathrm{mRS}$ score $\geq 4$ for 4 weeks; clinical improvement was defined as a decrease in the $\mathrm{mRS}$ score $\geq 1$ point from that at the previous visit; relapse was defined as an exacerbation of previous symptoms or the occurrence of new symptoms after being stable for 2 months. Long-term favorable outcome was defined as an $\mathrm{mRS}$ score $\leq 2$, and poor outcome was defined as an $\mathrm{mRS}$ score $>2$ at the end of follow-up.

\section{Statistical analysis}

Statistical analyses were performed using SPSS IBM 20.0. GraphPad Prism 6.0 was used to generate figures. Quantitative data with normal distributions are presented as mean \pm $\mathrm{SD}$, otherwise as medians with the interquartile range (IQR). The mRS scores before and after treatment were compared using the Wilcoxon test. Symptoms and demographic data were analyzed using the $\chi^{2}$ test or Fisher exact test for categorical variables and Mann-Whitney $U$ test for continuous variables. Factors affecting outcome were assessed using binary logistic regression analysis. Kaplan-Meier curves with log-rank were used to analyze relapse frequency. $p<0.05$ was considered significant.

\section{Standard protocol approvals, registrations, and patient consents}

This study was approved by the Ethics Committee of PUMCH (JS-891), and informed consent was obtained from each patient. All the data analyzed in the study were strictly anonymous.

\section{Data availability}

Anonymized data not published within this article will be made available by request from any qualified investigator. 
Results

\section{Clinical characteristics}

A total of 220 patients were enrolled, and all were tested for anti-NMDAR antibody with paired CSF and serum. All patients $(100 \%)$ were positive for anti-NMDAR antibodies in CSF, and 157 (71.4\%) were positive in serum. Review of the enrolled patients indicated that all patients met the diagnostic criteria proposed by Graus et al. ${ }^{3}$

The median age at onset was 21 (range 5-72) years, with 69 (31.4\%) of the patients younger than 18 years. Overall, 143 (65.0\%) patients were females, and 77 (35.0\%) were males. Tumors were found in 43 (19.5\%) patients: 42 females with ovarian teratomas and 1 male with lung cancer. All the female patients with ovarian teratomas underwent tumor removal, whereas the patient with lung cancer was treated with palliative therapy by an internist and later died of cancer. In addition, 8 patients were found to have prominent moles on the body surface, which were later resected. Pathologically, the moles were compound or intradermal nevi. ${ }^{17,18}$

The most common clinical manifestations of the antiNMDAR encephalitis were psychosis (182, 82.7\%) and seizures (178, 80.9\%). Movement disorder presented more often in patients younger than 18 years than adult patients $(38 / 69,55.1 \%$ vs $56 / 151,37.1 \%, p=0.01)$. Table 1 describes the patients' clinical characteristics in detail.

Figure 1 shows the distribution of female patients according to age and presence vs absence of tumor; the peak cooccurrence of ovarian teratoma was between 19 to 24 years.

\section{Ancillary test results}

All patients underwent brain MRI at onset, and 79 (35.9\%) had abnormal fluid-attenuated inversion recovery sequence signals, including 31 (14.1\%) in the medial temporal lobe. Other involved areas included the frontal, parietal, and occipital cortices, diencephalon, cerebellum, and brainstem. Eleven (5.0\%) patients had demyelinating lesions, of whom 4 were positive for aquaporin-4 (AQP4) antibody and 5 for myelin oligodendrocyte glycoprotein (MOG) antibody. Abnormal EEG findings were seen in 113 (51.4\%) patients: 102 (46.4\%) had slow activity and 14 (6.4\%) epileptic discharges. However, as most patients received short-duration EEG instead of video EEG of 24 hours or longer, the percentage of delta-brush abnormality was unable to assess.

Repeated lumbar punctures were performed for diagnosis and evaluation, and the CSF results at onset before immunotherapy were collected and analyzed. The analysis showed a median opening pressure of 170 (IQR $150-280$ ) $\mathrm{mmH}_{2} \mathrm{O}$. Of note, $81.3 \%$ of the patients had pleocytosis, the median white blood cell count was 14.0 (IQR 7.0-22.5) × 10\% $/ \mathrm{L}$, and $90.9 \%$ were of mononuclear cells (i.e., lymphocyte and monocytes). The protein level was elevated in $29.7 \%$ of the patients. Table 2 summarizes the main ancillary tests of the patients.
Table 1 Clinical characteristics of patients with antiNMDA receptor encephalitis

\begin{tabular}{|c|c|c|c|c|}
\hline \multirow[b]{2}{*}{$\begin{array}{l}\text { Clinical } \\
\text { characteristics }\end{array}$} & \multicolumn{3}{|c|}{ No. of patients (percentage) } & \multirow[b]{2}{*}{$\begin{array}{l}p \\
\text { Value }\end{array}$} \\
\hline & $\begin{array}{l}\text { All } \\
(n=220)\end{array}$ & $\begin{array}{l}\text { Age }<18 \text { y } \\
(n=69)\end{array}$ & $\begin{array}{l}\text { Age }>18 y \\
(n=151)\end{array}$ & \\
\hline $\begin{array}{l}\text { Median age, } \\
\text { range }(y)\end{array}$ & $21(5-72)$ & $15(5-17)$ & $26(18-72)$ & \\
\hline Female & $143(65.0)$ & $41(59.4)$ & $102(67.5)$ & 0.24 \\
\hline Psychosis & $182(82.7)$ & $57(82.6)$ & $125(82.8)$ & 0.98 \\
\hline Seizures & $178(80.9)$ & $56(81.2)$ & $122(80.8)$ & 0.95 \\
\hline Fever & $126(57.3)$ & $41(59.4)$ & $85(56.3)$ & 0.67 \\
\hline $\begin{array}{l}\text { Decreased level of } \\
\text { consciousness }\end{array}$ & $117(53.2)$ & $35(50.7)$ & $82(54.3)$ & 0.62 \\
\hline Memory deficit & $106(48.2)$ & $28(40.6)$ & 78 (51.7) & 0.13 \\
\hline Speech disturbance & $100(45.5)$ & $30(43.5)$ & $70(46.4)$ & 0.69 \\
\hline Movement disorder & $94(42.7)$ & $38(55.1)$ & $56(37.1)$ & 0.01 \\
\hline Sleep disorder & $93(42.3)$ & $27(12.3)$ & $66(30.0)$ & 0.52 \\
\hline Headache & $86(39.1)$ & $21(30.4)$ & $65(43.0)$ & 0.08 \\
\hline $\begin{array}{l}\text { Admission to } \\
\text { the ICU }\end{array}$ & 68 (30.9) & $18(26.1)$ & $50(33.1)$ & 0.30 \\
\hline $\begin{array}{l}\text { Mechanical } \\
\text { ventilation }\end{array}$ & $44(20.0)$ & $12(17.4)$ & $32(21.2)$ & 0.51 \\
\hline $\begin{array}{l}\text { Central } \\
\text { hypoventilation }\end{array}$ & 39 (17.7) & $9(13.0)$ & 30 (19.9) & 0.22 \\
\hline Arrhythmia & $34(15.5)$ & $12(17.4)$ & $22(14.6)$ & 0.59 \\
\hline Limb weakness & $24(10.9)$ & $9(13.0)$ & $15(9.9)$ & 0.49 \\
\hline Ataxia & $11(5.0)$ & $4(5.8)$ & $7(4.6)$ & 0.74 \\
\hline $\begin{array}{l}\text { Ovarian teratoma of } \\
\text { female patients }\end{array}$ & $42(29.4)$ & $9(22.0)$ & $33(32.4)$ & 0.22 \\
\hline
\end{tabular}

Abbreviation: ICU = intensive care unit.

\section{Improvements in diagnosis accuracy and general hospitalization status}

Underrecognition and misdiagnosis were inevitable in the past, occurring at the initial visit to a local physician or admission to our hospital. In 2011, 4 patients were identified, taking a median duration of 9 (IQR 1-36) months before diagnosis was made. The misdiagnosis rate then was $75.0 \%$, with most cases misdiagnosed as viral encephalitis.

With increased awareness of AE, screening for anti-NMDAR antibodies at admission is now required for all cases with suspected encephalitis. By 2017, the misdiagnosis rate had decreased to $15.4 \%$. Overall, 30 patients were misdiagnosed with viral encephalitis, 10 with schizophrenia, 2 with epilepsy, and 1 each with cerebral angiitis, cerebral vascular events, and tuberculosis. The percentages of correct diagnosis at the initial hospital visit over misdiagnosis by calendar year were shown in figure 2, indicating a growing 


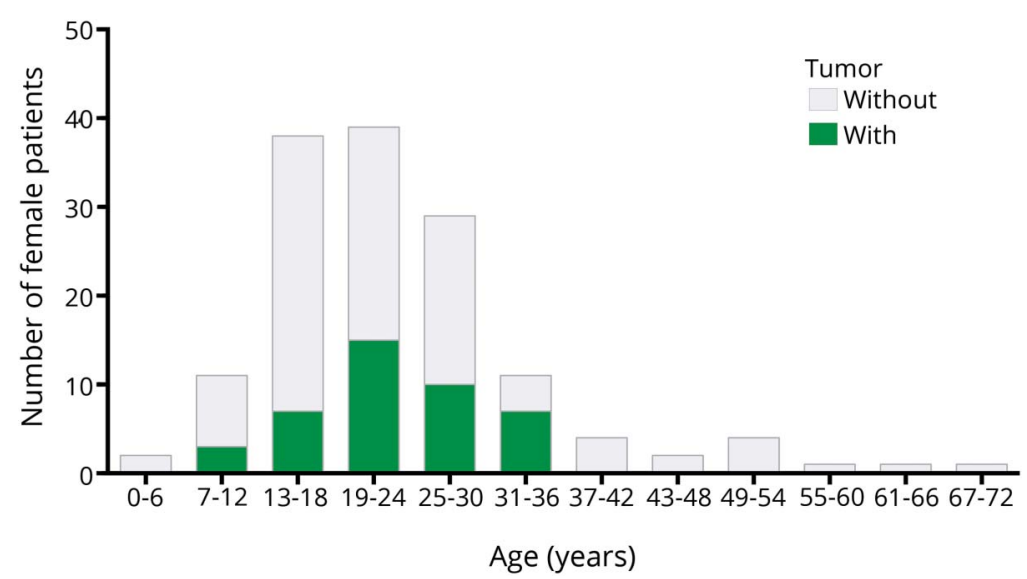

number of referred patients and increased correct diagnosis identified over the years.

The median duration from onset to diagnosis was 2 (IQR 1-4) weeks. Immunotherapy was initiated the same day diagnosis was made and sometimes even before diagnosis at local hospitals as empirical treatment. The median length of hospitalization was 26 (IQR 14-42) days. However, severe patients who required intensive care stayed in the hospital for up to 117 days.

\section{Treatment outcomes}

Overall, 219 (99.5\%) patients received first-line immunotherapy, in most cases a combined regimen of repeated steroids and IVIG. A total of 208 (94.5\%) patients received steroids, of whom 103 (46.8\%) received pulsed IV methylprednisolone. IVIG was administered to 199 (90.5\%) patients, and 7 (3.2\%) patients underwent PE. Second-line immunotherapy was administered to only a small proportion of the patients, usually because of the off-label use of RTX in $\mathrm{AE}$, cost, IV and hospitalization requirements, and concerns about side effects. Twelve (5.5\%) patients received RTX, and $4(1.8 \%)$ received CTX. Long-term immunotherapy was administered mainly in patients who were enrolled later, as an add-on therapy for severe or refractory patients in the acute phase, or as maintenance therapy to prevent and manage relapses. In general, MMF was administered in 109 (49.5\%) patients, 55 of whom at onset and 54 after relapse, and AZA was administered in $8(3.6 \%)$ patients. In addition, intrathecal MTX was given to $8(3.6 \%)$ severe patients.

During the first 12 months, 207 (94.1\%) patients experienced improvement, 8 (3.6\%) were stable, and 5 (2.3\%) patients died. All survival patients were followed for at least a year (range 12-72 months). At 12-month follow-up, 204 (92.7\%) patients had attained satisfactory neurologic function ( $\mathrm{mRS}$ score of 0 , 1 , and 2 in 144, 47, and 13 patients, respectively) compared with $23(10.5 \%)$ patients with an $\mathrm{mRS}$ score $\leq 2$ at onset, as shown in figure 3 . The median $\mathrm{mRS}$ score at the last follow-up was 0 (IQR 0-1), which was significantly lower than the score of 4 (IQR 3-5) at onset $(Z=-12.67, p<0.0001)$.

Table 3 summarizes the comparisons between patients with favorable and poor clinical outcomes. Of interest, more patients with speech disturbance were identified in the favorable outcome group $(p=0.03)$. Further analysis indicated that patients with speech disturbance presented to the neurologist earlier than those without (20 days [IQR 12-34 days] vs 31 days [IQR 19-58 days], $p=0.008, \mathrm{Z}=-2.665$ ). However, age at onset, the rates of decreased consciousness level, central hypoventilation, ICU admission, mechanical ventilation, ovarian teratoma, and relapse were higher in the poor outcome subgroup, although none of these differences reached significance.

\section{Relapse}

During the first 12 months, 38 (17.3\%) patients experienced a first relapse. Their median age was 21 (IQR 16-37) years, and the median duration from onset to the first relapse was 7 (IQR 5-10) months. Of the relapsed patients, 25 (65.8\%) were female, and 5 had ovarian teratomas at disease onset.

Thorough clinical and laboratory examinations were conducted to rule out other etiologies and to validate the diagnosis. Two patients were treated at local hospitals before antibodies were tested, whereas 10/36 (27.8\%) patients showed elevated antibody titer at relapse during serial serum antibody monitoring. Of the 17 patients who underwent lumbar puncture, CSF antibodies were detected in $15(88.2 \%)$ patients. MRI was abnormal in $8(21.1 \%)$ patients, and an ovarian teratoma was detected in only $1(2.6 \%)$ patient at relapse. A delay in treatment was associated with relapse $(p<0.01)$.

However, neither tumor status $(p=0.58)$ nor treatment regimen $(p=0.34)$ was statistically associated with relapse frequency (figure e-1, links.lww.com/NXI/A157). 
Table 2 Summary of the main ancillary tests results

Number (percentage)

\begin{tabular}{|c|c|c|}
\hline & \multicolumn{2}{|c|}{ Number (percentage) } \\
\hline \multicolumn{3}{|l|}{ Brain MRI } \\
\hline Total with abnormal findings & \multicolumn{2}{|c|}{$79(35.9)$} \\
\hline Medial temporal lobe & \multicolumn{2}{|c|}{$31(14.1)$} \\
\hline Frontal lobe & \multicolumn{2}{|c|}{$20(9.1)$} \\
\hline Parietal lobe & \multicolumn{2}{|c|}{$13(5.9)$} \\
\hline Occipital lobe & \multicolumn{2}{|c|}{$13(5.9)$} \\
\hline Diencephalon & \multicolumn{2}{|c|}{$2(0.9)$} \\
\hline Cerebellum & \multicolumn{2}{|c|}{$3(1.4)$} \\
\hline Brainstem & \multicolumn{2}{|c|}{$6(2.7)$} \\
\hline Demyelinating lesion & \multicolumn{2}{|c|}{$11(5.0)$} \\
\hline Anti-AQP4 Ab(+) & \multicolumn{2}{|c|}{$4(1.8)$} \\
\hline Anti-MOG Ab(+) & \multicolumn{2}{|c|}{$5(2.3)$} \\
\hline \multicolumn{3}{|l|}{ EEG } \\
\hline Total with abnormal findings & \multicolumn{2}{|c|}{$113(51.4)$} \\
\hline Epileptic discharges & \multicolumn{2}{|c|}{$14(6.4)$} \\
\hline Slow activity & \multicolumn{2}{|c|}{$102(46.4)$} \\
\hline $\begin{array}{l}\text { CSF analysis (information of } \\
64 \text { patients) }\end{array}$ & Median (IQR) & $\begin{array}{l}\text { Number } \\
\text { (percentage) }\end{array}$ \\
\hline Opening pressure $\left(\mathrm{mmH}_{2} \mathrm{O}\right)$ & \multicolumn{2}{|l|}{$170(150-280)$} \\
\hline WBC $\left(\times 10^{6} / L\right)$ & \multicolumn{2}{|l|}{$14.0(7.0-22.5)$} \\
\hline Pleocytosis & \multicolumn{2}{|c|}{$52(81.3)$} \\
\hline $\begin{array}{l}\text { Percentage of mononuclear } \\
\text { cells }(\%)\end{array}$ & \multicolumn{2}{|l|}{$90.9(83.1-99) \%$} \\
\hline \multirow[t]{2}{*}{ Protein $(\mathrm{g} / \mathrm{L})$} & \multicolumn{2}{|l|}{$0.30(0.21-0.42)$} \\
\hline & $\geq 0.45$ & 19 (29.7) \\
\hline Positive SOB & & $16(25.0)$ \\
\hline Glucose (mmol/L) & & $3.5(3.1-4.2)$ \\
\hline Chloride (mmol/L) & & $123(120-125)$ \\
\hline
\end{tabular}

Abbreviations: $\mathrm{AQP} 4$ = aquaporin-4; IQR = interquartile range; $\mathrm{MOG} \mathrm{Ab}=$ myelin oligodendrocyte glycoprotein antibody; SOB = specific oligoclonal band; $\mathrm{WBC}=$ white blood cell count.

Mononuclear cells: lymphocytes and monocytes.

CSF-SOB is defined as bands that are present in CSF but are absent in serum. Positive SOB is defined as at least 1 specific band in the CSF.

All relapsed patients underwent reinitiation of the first-line immunotherapy, and 18 patients were also given long-term MMF. Subsequently, 12 (31.6\%) patients experienced further relapses (range 2-4 episodes). There was no significant difference in the occurrence of subsequent relapse between MMF-treated patients and other patients $(4 / 18,22.2 \%$ vs $8 / 20,40.0 \%, p=0.31)$.

Subsequent relapses were similar to, or worse than, the initial episodes in only 3 (7.9\%) patients. The initial hospitalization duration was 25 (IQR 14-43) days, and the subsequent hospitalizations were all shorter than 14 days.

Between 2011 and 2017, 80 (36.4\%) patients experienced relapse, and 21 (26.3\%) experienced multiple relapses (range 2-4 episodes). Most patients had a first relapse during the first 24 months $(64 / 80,80.0 \%)$. However, relapses up to 6 years after onset were also reported in our cohort.

\section{Discussion}

To our knowledge, this is the largest Chinese anti-NMDAR encephalitis cohort to date. In our study, anti-NMDAR encephalitis is predominantly found in females $(65.0 \%)$ with the median age at onset of 21 years. Most patients presented with psychiatric symptoms and seizures, and younger patients presented more often with movement disorders, which are consistent with previous studies. ${ }^{6,7}$

However, our study reported a low ICU admission rate. The large cohort study of Titulaer et al. ${ }^{7}$ reported that $75 \%$ $(435 / 563)$ of patients with $\mathrm{mRS}$ score $\geq 4$ were admitted to the ICU. In our study, because of limited availability of medical recourses and concern of expenses, only 68/133 (51.1\%) of the severe patients ( $\mathrm{mRS}$ score $\geq 4$ ) were admitted to the ICU.

The prevalence of an underlying neoplasm varied among studies. Titulaer et al. ${ }^{7}$ reported that $38 \%$ of the patients had a tumor, and Asian patients were more likely (45\%) to have a teratoma. However, only $19.5 \%$ of the patients in our cohort had a tumor, with $29.4 \%$ of the females had an ovarian teratoma. Other studies of Chinese or Asian patients have also reported low prevalence of tumors (Lim et al., 22.7\%; Wang et al., $8 \%$; Liu et al., 6.7\%; and Zhang et al., 8.1\%)., ${ }^{8,11,13,14}$ The heterogeneity among reports may be due to sample sizes and selection bias or other factors including genetic backgrounds and epidemiologic reasons, and future studies are required.

In tumor-negative patients, herpes simplex virus (HSV) infection has been reported to be the possible trigger. However, as the gold standard for the infection is PCR testing, which is expensive and time consuming, most patients received empirical treatment before or even without a definite diagnosis of HSV encephalitis. Thus post-HSV anti-NMDAR encephalitis was unable to assess in our current study.

Brain MRI findings provide further evidence that antiNMDAR encephalitis is a "diffuse encephalopathy." Abnormal signals were reported in $35.9 \%$ of the patients, predominantly in the medial temporal lobe. Signals in other areas of the cortex, diencephalon, brainstem, and cerebellum were also reported.

Notably, "overlapping syndrome" was identified in 11 (5.0\%) patients with both MRI demyelinating lesions and anti-AQP4 or anti-MOG antibodies. ${ }^{19}$ Studies have suggested more 


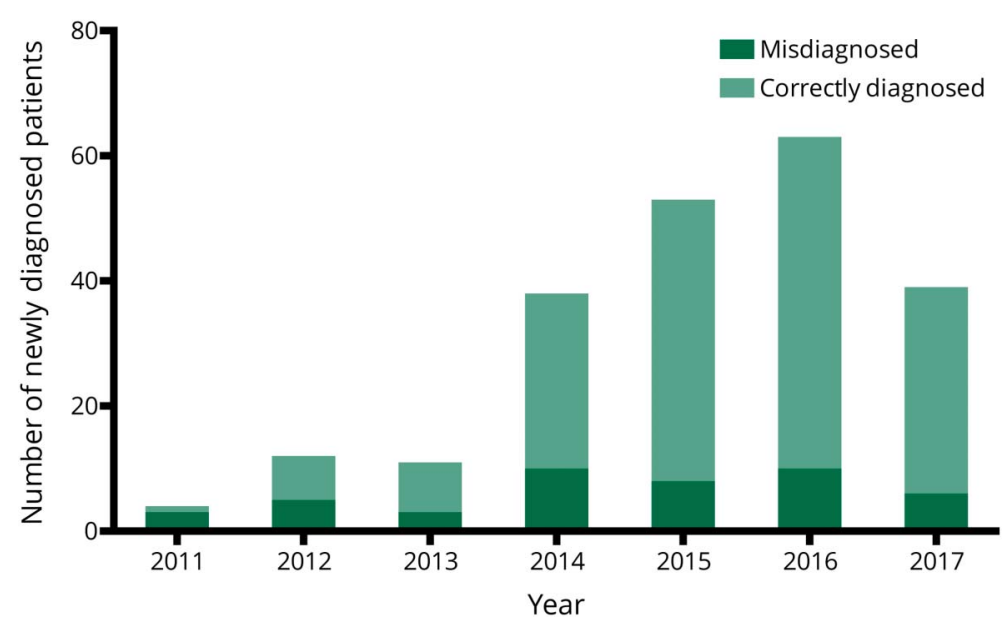

intense immunotherapy requirements and more residual deficits in these patients. ${ }^{19,20}$ In our series, all these patients received long-term immunotherapy with $\mathrm{MMF}$, and $10(90.9 \%)$ had favorable clinical outcomes.

In the management of anti-NMDAR encephalitis, repeated first-line immunotherapy was frequently used in our cohort, whereas second-line immunotherapy was administered in a small portion of patients owing to the off-label use of RTX for $\mathrm{AE}$ in China, cost, hospitalization requirements, and concerns about side effect. ${ }^{9,11,14,15}$ However, long-term immunotherapy was administered to 117 (53.2\%) patients, including MMF to 109 (49.5\%). With combined therapy of re-enforced first-line therapy and long-term immunotherapy, 204 (92.7\%) patients reached favorable clinical outcomes, and the median mRS score decreased significantly from 4 to 0 at a follow-up of 12 months. Compared with other reports (Dalmau et al., 77\%; Tituaer et al., 79\%; Wang et al., 80.4\%; Liu et al., 64\%; and Zhang et al., $89.2 \%)$, 6,7,11,13,14 we observed more satisfactory clinical outcomes. Speech disturbance was found to be more frequent in the group with favorable outcome. Further analysis indicated that patients with speech distance were diagnosed earlier. Thus, this could be a confounder reflecting better recognition and therefore quicker treatment.

Relapses were relatively common in our cohort. The definition of relapse in our study, along with other proposed definitions, ${ }^{7,21,22}$ is based more on observations and descriptions of clinical symptoms. Nevertheless, thorough examinations are needed to rule out other disorders and validate the diagnosis. When monitoring and evaluating the relapses, MRI was frequently unremarkable. The serum antibody titer did not correlate with the clinical severity perfectly, and some relapsed antibodies were detected only in the CSF, as previously reported. ${ }^{6,22}$ However, serial CSF monitoring may be impractical during follow-up, and better indicators should be identified in future studies. Neither tumor status nor treatment regimen was associated with relapse frequency statistically, possibly due to the low prevalence of tumor and variety in the treatment regimens used in our cohort. Long-term MMF did not prevent further relapses, possibly because of the relatively small sample size, and the role of long-term immunotherapy warrants further investigation. Although most patients experienced a first relapse within 24 months, relapse 6 years after onset was also reported. Other reports also suggested that $\mathrm{AE}$ relapse could occur years after the initial episode. ${ }^{21,23,24}$ Therefore, extended follow-up is essential. Our study has several limitations. As the national referral center for complicated disease, our cohort may be biased by more refractory cases. The analysis for each individual treatment, particularly for long-term immunotherapy, and the assessment of relapses warrants further study. Parameters other

Figure 3 Distribution of mRS scores at onset and last follow-up

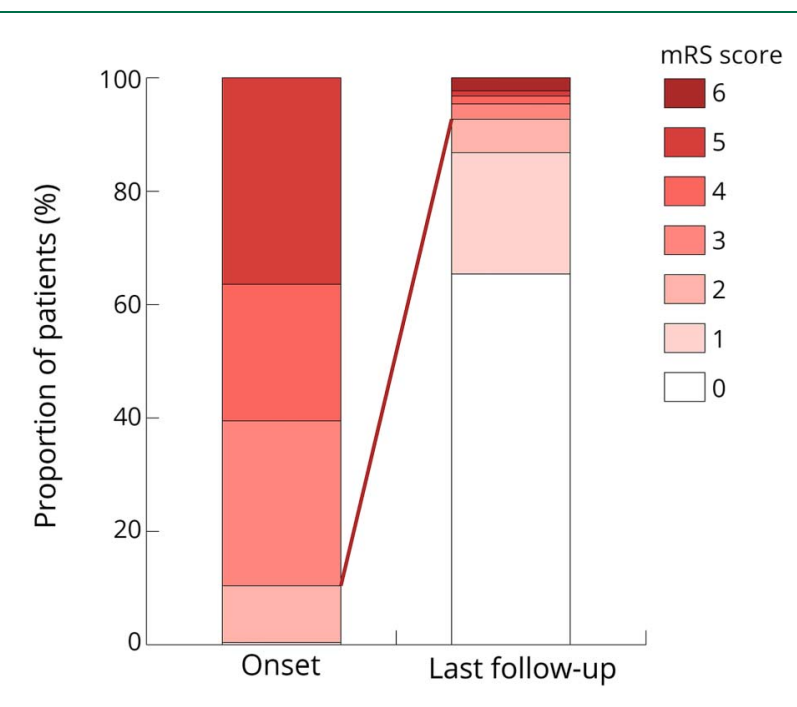

$\mathrm{mRS}=$ modified Rankin Scale. 
Table 3 Comparisons of clinical data of patients with anti-NMDA receptor encephalitis

\begin{tabular}{|c|c|c|c|c|}
\hline & Favorable outcome $(n=204)$ & Poor outcome $(n=16)$ & $\mathrm{Z} / \chi^{2}$ value & $p$ Value \\
\hline Age (y) & $21(16-28)$ & $27(20-32)$ & -1.79 & 0.07 \\
\hline \multicolumn{5}{|l|}{$\operatorname{Sex}(n, \%)$} \\
\hline Male & $71(34.8)$ & $6(37.5)$ & 0.05 & 0.83 \\
\hline Female & $133(65.2)$ & $10(62.5)$ & & \\
\hline \multicolumn{5}{|l|}{ Symptoms (n, \%) } \\
\hline Fever & $118(57.8)$ & $7(43.8)$ & 1.20 & 0.27 \\
\hline Headache & $80(39.2)$ & $5(31.3)$ & 0.40 & 0.53 \\
\hline Psychosis & $170(83.3)$ & $11(68.8)$ & 2.16 & 0.17 \\
\hline Memory deficit & $100(49.0)$ & $5(31.3)$ & 1.88 & 0.17 \\
\hline Seizures & $165(80.9)$ & $12(75.0)$ & 0.33 & 0.52 \\
\hline Decreased level of consciousness & $106(52.0)$ & $10(62.5)$ & 0.66 & 0.42 \\
\hline Movement disorder & $87(42.7)$ & $6(37.5)$ & 0.16 & 0.69 \\
\hline Speech disturbance & $96(47.1)$ & $3(18.8)$ & 4.80 & 0.03 \\
\hline Central hypoventilation & $35(17.2)$ & $4(25.0)$ & 0.63 & 0.49 \\
\hline ICU admission & $61(29.9)$ & $7(43.8)$ & 1.33 & 0.27 \\
\hline Mechanical ventilation & $40(19.6)$ & $4(25.0)$ & 0.27 & 0.53 \\
\hline Arrhythmia & $32(15.7)$ & $2(12.5)$ & 0.12 & 0.73 \\
\hline Ataxia & $9(4.4)$ & $2(12.5)$ & 2.04 & 0.19 \\
\hline Limb weakness & $22(10.8)$ & $2(12.5)$ & 0.05 & 0.69 \\
\hline Ovarian teratoma ${ }^{a}$ & $37(27.8)$ & $5(50.0)$ & 2.21 & 0.16 \\
\hline \multicolumn{5}{|l|}{ CSF analysis of acute phase $(n, \%)$} \\
\hline Pleocytosis $^{\mathbf{b}}$ & $88(58.7)$ & $4(44.4)$ & 0.70 & 0.40 \\
\hline Increased level of protein ${ }^{c}$ & $33(24.6)$ & $3(33.3)$ & 0.34 & 0.56 \\
\hline Positive SOBd & $48(50.5)$ & $2(28.6)$ & 1.26 & 0.26 \\
\hline Abnormal brain MRI signal $(n, \%)$ & $72(35.3)$ & $7(43.8)$ & 0.46 & 0.50 \\
\hline Abnormal EEG findings $(n, \%)^{e}$ & $110(80.9)$ & $6(75.0)$ & 0.17 & 0.68 \\
\hline Diagnosis duration (mo) & 1.0 & 1.0 & I & l \\
\hline \multicolumn{5}{|l|}{ Immunotherapy (n, \%) } \\
\hline Steroids & $194(95.1)$ & $14(87.5)$ & 1.66 & 1.20 \\
\hline IVIG & $184(90.2)$ & $15(93.8)$ & 0.22 & 0.64 \\
\hline MMF & $103(50.5)$ & $6(37.5)$ & 1.51 & 0.17 \\
\hline Baseline mRS score >2 $(n, \%)$ & $183(89.7)$ & $14(87.5)$ & 0.08 & 0.78 \\
\hline Relapsed patient (n, \%) & $73(35.8)$ & $7(43.8)$ & 0.41 & 0.52 \\
\hline
\end{tabular}

Abbreviations: ICU = intensive care unit; IVIG = IV immunoglobulin; MMF = mycophenolate mofetil; mRS = modified Rankin Scale; SOB = specific oligoclonal band.

${ }^{a}$ Analysis of 143 female patients.

${ }^{\mathrm{b}}$ Analysis of 159 patients with results available.

'Analysis of 143 patients with results available.

${ }^{d}$ Analysis of 102 patients with results available.

e Analysis of 144 patients with results available. 
than the mRS score are required to describe fully the outcomes of anti-NMDAR encephalitis, especially in evaluating the cognitive or behavioral function, which usually remains last in these patients. Despite these limitations, our study adds to the present knowledge of anti-NMDAR encephalitis, and acts as a precursor for future multicenter studies with more comprehensive evaluations, and studies to further evaluate the efficacy of each individual treatment.

We describe the clinical characteristics, immunotherapy regimens, and long-term outcomes of patients with antiNMDAR encephalitis in China. Repeated first-line therapy is effective in managing acute phase encephalitis, and the efficacy of long-term immunotherapy warrants further study. Although relapses are relatively common, most patients reached favorable outcomes. Further multicenter studies with more advanced study design, more detailed evaluation, and extended follow-up are required.

\section{Acknowledgment}

The authors thank Prof. Jianming Wang of Peking Union Medical College Hospital and Prof. Jiawei Wang of Beijing Tongren Hospital Affiliated to Capital Medical University for providing advice for the article. They also thank Dr. Yan Zhang of Xuanwu Hospital Affiliated to Capital Medical University, Dr. Yongqiang Hu of Beijing Fengtai Youanmen Hospital, and Beijing Encephalitis Group for contributing participants.

\section{Study funding}

The study was supported by (1) National Key Research and Development Program of China (Grant no. 2016YFC0901500); (2) Center for Rare Diseases Research, Chinese Academy of Medical Sciences, Beijing, China (Grant no. 2016ZX310174-4); and (3) Beijing Municipal Science and Technology Foundation (Grant no. Z161100000516094).

\section{Disclosure}

The authors report no disclosures. Go to Neurology.org/NN for full disclosures.

\section{Publication history}

Received by Neurology: Neuroimmunology \& Neuroinflammation April 21, 2019. Accepted in final form September 12, 2019.

Appendix Authors

\begin{tabular}{llll}
\hline Name & Location & Role & Contribution \\
\hline $\begin{array}{l}\text { Xiaolu } \\
\text { Xu, MD }\end{array}$ & $\begin{array}{l}\text { Peking Union } \\
\text { Medical College } \\
\text { Hospital, Beijing, } \\
\text { China }\end{array}$ & Author & $\begin{array}{l}\text { Analyzed the data and } \\
\text { drafted the manuscript for } \\
\text { intellectual content }\end{array}$ \\
\hline $\begin{array}{l}\text { Qiang Lu, } \\
\text { MD }\end{array}$ & $\begin{array}{l}\text { Peking Union } \\
\text { Medical College } \\
\text { Hospital, Beijing, } \\
\text { China }\end{array}$ & Author & $\begin{array}{l}\text { Analyzed the data and } \\
\text { drafted the manuscript for } \\
\text { intellectual content }\end{array}$ \\
& &
\end{tabular}

Appendix (continued)

\begin{tabular}{llll}
\hline Name & Location & Role & Contribution \\
\hline $\begin{array}{l}\text { Yan } \\
\text { Huang, } \\
\text { MD }\end{array}$ & $\begin{array}{l}\text { Peking Union } \\
\text { Medical College } \\
\text { Hospital, Beijing, } \\
\text { China }\end{array}$ & Author & $\begin{array}{l}\text { Major role in the } \\
\text { acquisition of data and } \\
\text { analyzed the data }\end{array}$ \\
\hline $\begin{array}{l}\text { Siyuan } \\
\text { Fan, MD }\end{array}$ & $\begin{array}{l}\text { Peking Union } \\
\text { Medical College } \\
\text { Hospital, Beijing, } \\
\text { China }\end{array}$ & Author & $\begin{array}{l}\text { Major role in the } \\
\text { acquisition of data and } \\
\text { analyzed the data }\end{array}$ \\
\hline $\begin{array}{l}\text { Lixin } \\
\text { Zhou, MD }\end{array}$ & $\begin{array}{l}\text { Peking Union } \\
\text { Medical College } \\
\text { Hospital, Beijing, } \\
\text { China }\end{array}$ & Author & $\begin{array}{l}\text { Analyzed the data and } \\
\text { revised the manuscript for } \\
\text { intellectual content }\end{array}$ \\
& & & \\
\hline
\end{tabular}

\begin{tabular}{lll}
\hline Jing & $\begin{array}{l}\text { Peking Union } \\
\text { Yuan, MD }\end{array}$ & Author \\
& $\begin{array}{l}\text { Medical College } \\
\text { Hospital, Beijing, } \\
\text { China }\end{array}$ & $\begin{array}{l}\text { Analyzed the data and } \\
\text { revised the manuscript for } \\
\text { intellectual content }\end{array}$
\end{tabular}

\begin{tabular}{llll}
\hline $\begin{array}{l}\text { Xunzhe } \\
\text { Yang, MD }\end{array}$ & $\begin{array}{l}\text { Peking Union } \\
\text { Medical College } \\
\text { Hospital, Beijing, } \\
\text { China }\end{array}$ & Author & $\begin{array}{l}\text { Interpreted the data and } \\
\text { revised the manuscript for } \\
\text { intellectual content }\end{array}$ \\
\hline $\begin{array}{l}\text { Haitao } \\
\text { Ren }\end{array}$ & $\begin{array}{l}\text { Peking Union } \\
\text { Medical College } \\
\text { Hospital, Beijing, } \\
\text { China }\end{array}$ & Author & $\begin{array}{l}\text { Major role in the } \\
\text { acquisition of data; } \\
\text { interpreted the data; and } \\
\text { revised the manuscript for } \\
\text { intellectual content }\end{array}$ \\
\end{tabular}

\begin{tabular}{|c|c|c|c|}
\hline $\begin{array}{l}\text { Dawei } \\
\text { Sun, MD }\end{array}$ & $\begin{array}{l}\text { Peking Union } \\
\text { Medical College } \\
\text { Hospital, Beijing, } \\
\text { China }\end{array}$ & Author & $\begin{array}{l}\text { Major role in the } \\
\text { acquisition of data; } \\
\text { interpreted the data; and } \\
\text { revised the manuscript for } \\
\text { intellectual content }\end{array}$ \\
\hline $\begin{array}{l}\text { Yi Dai, } \\
\text { MD }\end{array}$ & $\begin{array}{l}\text { Peking Union } \\
\text { Medical College } \\
\text { Hospital, Beijing, } \\
\text { China }\end{array}$ & Author & $\begin{array}{l}\text { Major role in the } \\
\text { acquisition of data and } \\
\text { interpreted the data }\end{array}$ \\
\hline $\begin{array}{l}\text { Huadong } \\
\text { Zhu, MD }\end{array}$ & $\begin{array}{l}\text { Peking Union } \\
\text { Medical College } \\
\text { Hospital, Beijing, } \\
\text { China }\end{array}$ & Author & $\begin{array}{l}\text { Major role in the } \\
\text { acquisition of data and } \\
\text { interpreted the data }\end{array}$ \\
\hline $\begin{array}{l}\text { Yinan } \\
\text { Jiang, MD }\end{array}$ & $\begin{array}{l}\text { Peking Union } \\
\text { Medical College } \\
\text { Hospital, Beijing, } \\
\text { China }\end{array}$ & Author & $\begin{array}{l}\text { Major role in the } \\
\text { acquisition of data }\end{array}$ \\
\hline $\begin{array}{l}\text { Yicheng } \\
\text { Zhu, MD }\end{array}$ & $\begin{array}{l}\text { Peking Union } \\
\text { Medical College } \\
\text { Hospital, Beijing, } \\
\text { China }\end{array}$ & Author & $\begin{array}{l}\text { Designed and } \\
\text { conceptualized study and } \\
\text { revised the manuscript for } \\
\text { intellectual content }\end{array}$ \\
\hline $\begin{array}{l}\text { Bin Peng, } \\
\text { MD }\end{array}$ & $\begin{array}{l}\text { Peking Union } \\
\text { Medical College } \\
\text { Hospital, Beijing, } \\
\text { China }\end{array}$ & Author & $\begin{array}{l}\text { Designed and } \\
\text { conceptualized study and } \\
\text { revised the manuscript for } \\
\text { intellectual content }\end{array}$ \\
\hline $\begin{array}{l}\text { Liying } \\
\text { Cui, MD }\end{array}$ & $\begin{array}{l}\text { Peking Union } \\
\text { Medical College } \\
\text { Hospital, Beijing, } \\
\text { China }\end{array}$ & Author & $\begin{array}{l}\text { Designed and } \\
\text { conceptualized the study } \\
\text { and revised the } \\
\text { manuscript for intellectual } \\
\text { content }\end{array}$ \\
\hline
\end{tabular}

\begin{tabular}{|c|c|c|c|}
\hline $\begin{array}{l}\text { Hongzhi } \\
\text { Guan, } \\
\text { MD }\end{array}$ & $\begin{array}{l}\text { Peking Union } \\
\text { Medical College } \\
\text { Hospital, Beijing, } \\
\text { China }\end{array}$ & Author & $\begin{array}{l}\text { Designed and } \\
\text { conceptualized the study; } \\
\text { interpreted the data; and } \\
\text { revised the manuscript for } \\
\text { intellectual content }\end{array}$ \\
\hline
\end{tabular}




\section{References}

1. Dalmau J, Tuzun E, Wu HY, et al. Paraneoplastic anti-N-methyl-D-aspartate receptor encephalitis associated with ovarian teratoma. Ann Neurol 2007;61:25-36.

2. Dalmau J, Gleichman AJ, Hughes EG, et al. Anti-NMDA-receptor encephalitis: case series and analysis of the effects of antibodies. Lancet Neurol 2008;7:1091-1098.

3. Graus F, Titulaer MJ, Balu R, et al. A clinical approach to diagnosis of autoimmune encephalitis. Lancet Neurol 2016;15:391-404.

4. Iizuka T, Sakai F, Ide T, et al. Anti-NMDA receptor encephalitis in Japan: long-term outcome without tumor removal. Neurology 2008;70:504-511.

5. Irani SR, Bera K, Waters $\mathrm{P}$, et al. N-methyl-D-aspartate antibody encephalitis: temporal progression of clinical and paraclinical observations in a predominantly nonparaneoplastic disorder of both sexes. Brain 2010;133:1655-1667.

6. Dalmau J, Lancaster E, Martinez-Hernandez E, Rosenfeld MR, Balice-Gordon R. Clinical experience and laboratory investigations in patients with anti-NMDAR encephalitis. Lancet Neurol 2011;10:63-74.

7. Titulaer MJ, McCracken L, Gabilondo I, et al. Treatment and prognostic factors for long-term outcome in patients with anti-NMDA receptor encephalitis: an observational cohort study. Lancet Neurol 2013;12:157-165.

8. Lim JA, Lee ST, Jung KH, et al. Anti-N-methyl-d-aspartate receptor encephalitis in Korea: clinical features, treatment, and outcome. J Clin Neurol 2014;10:157-161.

9. Yuan J, Peng B, Guan H, et al. Immunotherapy strategy for 35 cases of severe anti-N methyl-D-aspartate receptor encephalitis. Natl Med J China 2016;96:1035-1039.

10. Bartolini L, Muscal E. Differences in treatment of anti-NMDA receptor encephalitis: results of a worldwide survey. J Neurol 2017;264:647-653.

11. Wang W, Li JM, Hu FY, et al. Anti-NMDA receptor encephalitis: clinical characteristics, predictors of outcome and the knowledge gap in southwest China. Eur J Neurol 2016;23:621-629.

12. Association NBoCM. Chinese expert consensus on the diagnosis and management of autoimmune encephalitis. Chin J Neurol 2017;50:91-98.

13. Liu L, Song ZH, Guo J, et al. Clinical analysis of 45 Chinese patients with anti-Nmethyl-D-aspartate receptor encephalitis. Chin J Neurol 2014;47:474-481.
14. Zhang Y, Liu G, Jiang M, Chen W, He Y, Su Y. Clinical characteristics and prognosis of severe anti-N-methyl-D-aspartate receptor encephalitis patients. Neurocrit Care 2018;29:264-272.

15. Guan HZ, Xu XL, Zhu YC, et al. Clinical and immunological analysis of mycophenolate mofetil treatment in anti-leucine-rich glioma-inactivated 1 encephalitis. Chin J Neurol 2018;51:281-287.

16. Yang XZ, Cui LY, Ren HT, Qu T, Guan HZ. Anti-NMDAR encephalitis after resection of melanocytic nevi: report of two cases. BMC Neurol 2015;15:165.

17. Yang XZ, Zhu HD, Ren HT, et al. Utility and safety of intrathecal methotrexate treatment in severe anti-N-methyl-D-aspartate receptor encephalitis: a pilot study. Chin Med J (Engl) 2018;131:156-160.

18. Yin $\mathrm{H}$, Zhu C, Ren $\mathrm{H}$, et al. Resection of melanocytic nevi as a potential treatment of anti-NMDAR encephalitis patients without tumor: report of three cases. Neurol Sci 2018;39:165-167.

19. Titulaer MJ, Hoftberger R, Iizuka T, et al. Overlapping demyelinating syndromes and anti-N-methyl-D-aspartate receptor encephalitis. Ann Neurol 2014;75: 411-428.

20. Fan S, Xu Y, Ren $\mathrm{H}$, et al. Comparison of myelin oligodendrocyte glycoprotein (MOG)-antibody disease and AQP4-IgG-positive neuromyelitis optica spectrum disorder (NMOSD) when they co-exist with anti-NMDA (N-methyl-D-aspartate) receptor encephalitis. Mult Scler Relat Disord 2018;20:144-152.

21. Gabilondo I, Saiz A, Galan L, et al. Analysis of relapses in anti-NMDAR encephalitis. Neurology 2011;77:996-999.

22. Gresa-Arribas N, Titulaer MJ, Torrents A, et al. Antibody titres at diagnosis and during follow-up of anti-NMDA receptor encephalitis: a retrospective study. Lancet Neurol 2014;13:167-177.

23. Arino H, Armangue T, Petit-Pedrol M, et al. Anti-LGI1-associated cognitive impairment: presentation and long-term outcome. Neurology 2016;87: $759-765$.

24. van Sonderen A, Thijs RD, Coenders EC, et al. Anti-LGI1 encephalitis: clinical syndrome and long-term follow-up. Neurology 2016;87:1449-1456. 


\title{
Neurology $^{\odot}$ \\ Neuroimmunology \& Neuroinflammation
}

\author{
Anti-NMDAR encephalitis: A single-center, longitudinal study in China \\ Xiaolu Xu, Qiang Lu, Yan Huang, et al. \\ Neurol Neuroimmunol Neuroinflamm 2020;7; \\ DOI 10.1212/NXI.0000000000000633
}

This information is current as of October 16, 2019

\section{Updated Information \& Services}

References

Citations

Subspecialty Collections

Permissions \& Licensing

Reprints including high resolution figures, can be found at: http://nn.neurology.org/content/7/1/e633.full.html

This article cites 24 articles, 0 of which you can access for free at: http://nn.neurology.org/content/7/1/e633.full.html\#\#ref-list-1

This article has been cited by 1 HighWire-hosted articles: http://nn.neurology.org/content/7/1/e633.full.html\#\#otherarticles

This article, along with others on similar topics, appears in the following collection(s):

All Clinical Neurology

http://nn.neurology.org//cgi/collection/all_clinical_neurology Autoimmune diseases

http://nn.neurology.org//cgi/collection/autoimmune_diseases

Information about reproducing this article in parts (figures,tables) or in its entirety can be found online at:

http://nn.neurology.org/misc/about.xhtml\#permissions

Information about ordering reprints can be found online:

http://nn.neurology.org/misc/addir.xhtml\#reprintsus

Neurol Neuroimmunol Neuroinflamm is an official journal of the American Academy of Neurology.

Published since April 2014, it is an open-access, online-only, continuous publication journal. Copyright

Copyright () 2019 The Author(s). Published by Wolters Kluwer Health, Inc. on behalf of the American

Academy of Neurology.. All rights reserved. Online ISSN: 2332-7812.

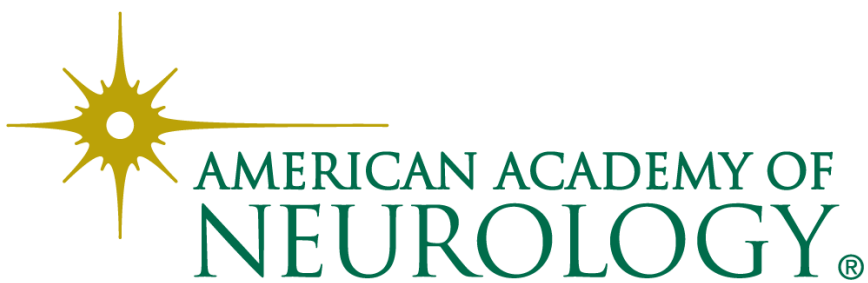

